\title{
A treatment for banknotes against viruses, bacteria and fungi
}

\author{
FN Renaud ${ }^{1 *}$, H Rosset $^{2}$, N Vast $^{3}$ \\ From International Conference on Prevention \& Infection Control (ICPIC 2011) \\ Geneva, Switzerland. 29 June - 2 July 2011
}

\section{Introduction / objectives}

Banknote paper was treated in order to prevent growth of micro organisms and consequently limit risks of contamination during handling.

\section{Methods}

The Biogard $\sqrt{ }{ }^{\circledR}$ paper substrate was treated by impregnation with patented harmless active compounds. Antibacterial activity against Eschericha coli and Staphylococcus aureus was determined using ISO 20743 (transfer method) standard, antifungal activity using AATCC 30 (part III) against Aspergillus niger and antiviral activity using EN $1447666+$ A1 standard against $\mathrm{H} 1 \mathrm{H} 1$ influenza A virus. Biocompatibility was assessed according to ISO 10993 standard with a skin irritation study in the rabbit and a sensitization study in the guinea pig.

\section{Results}

Antibacterial activity: no CFU was observed for both species after 24 hours of incubation. In these conditions the bacteria could not grow on the paper and were even killed. Antifungal activity: no growth on the surface paper was observed after 7 days of incubation. Aspergillus niger development was totally inhibited.

Antiviral activity: the reduction rate of viral titre was greater than 4 (4.15) showing that the paper had a strong virucidal activity against $\mathrm{H} 1 \mathrm{~N} 1$ influenza A virus after a contact time of 1 hour.

\section{Conclusion}

Banknotes are one of the most frequently-handled documents in the world. Most bacteria and fungi can survive a very long time on this kind of support. Even some virus can survive in specific environmental conditions.

${ }^{1}$ NOSOCO.TECH, UMR-CNRS-5510 MATEIS, Université Lyon1, Lyon, France Full list of author information is available at the end of the article
Moreover, it has been shown that banknotes can contribute to the transmission of pathogenic germs. The antimicrobial properties of Biogard $\sqrt{ }{ }^{\circledR}$ banknote treatment could be an innovative approach in infection control and contribute to preventing cross contaminations.

\section{Disclosure of interest}

None declared.

\section{Author details}

${ }^{1}$ NOSOCO.TECH, UMR-CNRS-5510 MATEIS, Université Lyon1, Lyon, France.

${ }^{2}$ Research \& Development, Arjowiggins Security, Apprieu, France. ${ }^{3}$ Marketing, Arjowiggins Security, Paris, France.

Published: 29 June 2011

doi:10.1186/1753-6561-5-S6-O37

Cite this article as: Renaud et al:: A treatment for banknotes against viruses, bacteria and fungi. BMC Proceedings 2011 5(Suppl 6):O37.

Submit your next manuscript to BioMed Central and take full advantage of:

- Convenient online submission

- Thorough peer review

- No space constraints or color figure charges

- Immediate publication on acceptance

- Inclusion in PubMed, CAS, Scopus and Google Scholar

- Research which is freely available for redistribution
C Biomed Central

(c) 2011 Renaud et al; licensee BioMed Central Ltc

Atributionaud et al; licensee BioMed Central Ltd. This is an open access article distributed under the terms of the Creative Commons any medium, provided the original work is properly cited. 